\title{
Temporal Associations between Community Incidence of COVID-19 and Nursing Home Outbreaks in Ontario, Canada
}

\author{
Kamil Malikov MD, MSc, MBA CPA, CMA ${ }^{1}$; Qing Huang MSc, PMP'; \\ Shengli Shi MD, MSc, MPH, $\mathrm{PhD}^{1}$; Nathan M. Stall MD ${ }^{2-5}$; \\ Ashleigh R. Tuite PhD, MPH ${ }^{6}$; Michael P. Hillmer MSc, $\mathrm{PhD}^{1,3}$ \\ ${ }^{1}$ Capacity Planning and Analytics Division, Ontario Ministry of Health, Toronto, Canada \\ ${ }^{2}$ Department of Medicine, University of Toronto, Toronto, Canada \\ ${ }^{3}$ Institute of Health Policy, Management and Evaluation, University of Toronto, Toronto, Canada \\ ${ }^{4}$ Women's College Research Institute, Women's College Hospital, Toronto, Canada \\ ${ }^{5}$ Division of General Internal Medicine and Geriatrics, Sinai Health System and the University Health Network, \\ Toronto, Canada \\ ${ }^{6}$ Dalla Lana School of Public Health, University of Toronto, Toronto, Canada
}

Corresponding author: Michael P. Hillmer MSc, $\mathrm{PhD}$

Assistant Deputy Minister, Capacity Planning and Analytics Division

Ontario Ministries of Health and Long-Term Care

1075 Bay Street, 13th Floor

Toronto, Ontario M5S 2B1 Canada

Phone: 416 327-0913

Email: Michael.Hillmer@ontario.ca

Word count: 714

Figures: 1

Tables: 1

References: 5

\begin{abstract}
The risk of nursing home COVID-19 outbreaks is strongly associated with the rate of infection in the communities surrounding homes, yet the temporal relationship between rising rates of community COVID-19 infection and the risk threshold for subsequent nursing home COVID-19 outbreaks is not well defined. This population-based cohort study included all COVID-19 cases in Canada's most populous Province of Ontario between March 1-July 16, 2020. We evaluated the temporal relationship between trends in the number of active community COVID-19 cases and the number of nursing home outbreaks. We found that the average lag time between community cases and nursing home outbreaks was 23 days for Ontario overall, with substantial variability across geographic regions. We also determined thresholds of community incidence of COVID-19 associated with a 75\% probability of observing a nursing home outbreak 5, 10 and 15 days into the future. For the province overall, when daily active COVID-19 community cases are 2.30 per 100,000 population, there is a $75 \%$ probability of a nursing home outbreak occurring five days later.
\end{abstract}


medRxiv preprint doi: https://doi.org/10.1101/2020.11.17.20233312; this version posted November 19, 2020. The copyright holder for this

It is made available under a CC-BY-NC-ND 4.0 International license .

\section{Background}

2 Nursing homes have borne the brunt of the COVID-19 pandemic, with residents of these homes

3 incurring extreme morbidity and mortality (1). The risk of nursing home COVID-19 outbreaks is

4 strongly associated with the rate of infection in the communities surrounding homes, with

5 infected health care workers being important and unknowing vectors for transmission into homes

6 (2, 3). The temporal relationship between rising rates of community COVID-19 infection and the

7 risk threshold for subsequent nursing home COVID-19 outbreaks is not well defined.

\section{Objective}

10 Evaluate and quantify the temporal relationship between community incidence of COVID-19

11 and subsequent risk of COVID-19 outbreaks in nursing homes in Ontario, Canada.

\section{Methods and Findings}

14 This population $\square$ based cohort study included all laboratory-confirmed COVID-19 cases in the

15 Province of Ontario, Canada (population >14-million) between March 1, 2020 (start of

16 community transmission of COVID-19) and July 16, 2020 (no new nursing home outbreak for

$17>7$-day period). We obtained data for this study from the Ontario Ministry of Health as part of

18 the province's emergency "modeling table," including deidentified line level data from the

19 integrated Public Health Information System on all reported COVID $\square 19$ cases for both

20 community and nursing home dwelling Ontario residents. We also obtained data on COVID-19

21 outbreaks from the province's Long-Term Care Inspections Branch COVID-19 case tracking

22 tool. In Ontario, a nursing home COVID-19 outbreak is defined as either one resident or staff

23 case and is declared over when there are no news cases within a 14-day period. All statistical

24 analyses were completed in SAS Statistical Software and Python. The study was approved by the

25 Research Ethics Board of the University of Toronto.

27 There was a total of 37,274 COVID-19 cases reported over this time period, of which 5,545

$28(14.8 \%)$ were reported among residents of 343 cumulative nursing home outbreaks. We assigned

29 all nursing homes to one of Ontario's five administrative health regions (West, Central, East,

30 North, and Toronto). We then evaluated the temporal relationship between trends in the number

31 of active community COVID-19 cases (cumulative cases less resolved cases and deaths) in each 
32 geographic region and the number of nursing home outbreaks (Figure 1). Active cases were used

33 because they are better reflective of the risk of infection in the population. We calculated

34 Pearson's correlation coefficients (r) between the number of nursing home outbreaks and daily

35 active community cases of COVID-19 in the days (1-50) preceding outbreaks, and ranked

36 coefficients by their descending values. The day with highest $r$ value was chosen as the 'lag day'

37 indicator. The average lag time between community cases and nursing home outbreaks was 23

38 days for Ontario overall, with substantial variability across geographic regions ranging from 11

39 to 43 days (Table 1). The longest lag was observed in the North Region, which has low

40 population density and reported a substantially lower cumulative COVID-19 incidence in

41 nursing home residents $(0.3 \%)$ compared to the provincial average $(7.5 \%)$ over this time period.

43 We next used logistic regression to model the probability of a nursing home outbreak with the

44 independent variable being active community COVID-19 cases, as above, in the preceding days

45 before an outbreak. We determined thresholds of community incidence of COVID-19 associated

46 with a $75 \%$ probability of observing a nursing home outbreak 5, 10 and 15 days into the future

47 (Table 1). For the province overall, when daily active COVID-19 community cases are 2.30 per

48100,000 population, there is a $75 \%$ probability of a nursing home outbreak occurring five days

49 later.

\section{Discussion}

52 Across Canada's most populous province of Ontario, increased community COVID-19

53 transmission portended a 23-day lagged rise in the number of nursing homes experiencing

54 COVID-19 outbreaks. Our findings also establish thresholds for community infections at which

55 outbreaks in nursing homes first occur. This is a useful early warning indicator when establishing

56 surveillance systems, and the lag days estimate provides a time window during which nursing

57 homes should rapidly mobilize occupational health and infection prevention and control

58 processes to both prevent and mitigate COVID-19 outbreaks.

60 Our analytic approach reinforces the importance of disaggregating community and nursing home

61 populations in models of COVID-19, and may also be applicable to other congregate care

62 settings including assisted living facilities (4). Our findings are also highly relevant to 
medRxiv preprint doi: https://doi.org/10.1101/2020.11.17.20233312; this version posted November 19, 2020. The copyright holder for this preprint (which was not certified by peer review) is the author/funder, who has granted medRxiv a license to display the preprint in perpetuity.

It is made available under a CC-BY-NC-ND 4.0 International license .

63 jurisdictions like the United States who are implementing phased approaches to reopening

64 nursing homes based on COVID-19 case status in the community (5).

Financial Support: This study was not funded. Dr. Stall is supported by the University of Toronto Department of Medicine's Eliot Phillipson Clinician-Scientist Training Program and the Vanier Canada Graduate Scholarship.

Disclosures: The authors have no conflicts of interest to disclose.

Reproducible Research Statement: Study protocol and statistical code: The study protocol and underlying analytic code are available from the authors on request (e-mail, kamil.malikov@ontario.ca), with the understanding that the computer programs may rely on coding templates or macros that are unique to the Ontario Ministry of Health and therefore either are inaccessible or may require modification. Data set: The data used for this study are not publicly available. 
medRxiv preprint doi: https://doi.org/10.1101/2020.11.17.20233312; this version posted November 19, 2020. The copyright holder for this preprint (which was not certified by peer review) is the author/funder, who has granted medRxiv a license to display the preprint in perpetuity.

It is made available under a CC-BY-NC-ND 4.0 International license.

\section{References}

1. Ouslander JG, Grabowski DC. COVID-19 in Nursing Homes: Calming the Perfect Storm. J Am Geriatr Soc. 2020.

2. Stall NM, Jones A, Brown KA, Rochon PA, Costa AP. For-profit long-term care homes and the risk of COVID-19 outbreaks and resident deaths. CMAJ. 2020;192(33):E946E55.

3. Fisman DN, Bogoch I, Lapointe-Shaw L, McCready J, Tuite AR. Risk Factors Associated With Mortality Among Residents With Coronavirus Disease 2019 (COVID19) in Long-term Care Facilities in Ontario, Canada. JAMA Netw Open. 2020;3(7):e2015957.

4. Pillemer K, Subramanian L, Hupert N. The Importance of Long-term Care Populations in Models of COVID-19. JAMA. 2020;324(1):25-6.

5. Centers for Medicare \& Medicaid Services 2020;Pageshttps://www.cms.gov/files/document/qso-20-30-nh.pdf-0 on May 182020. 
medRxiv preprint doi: https://doi.org/10.1101/2020.11.17.20233312; this version posted November 19, 2020. The copyright holder for this preprint (which was not certified by peer review) is the author/funder, who has granted medRxiv a license to display the preprint in perpetuity.

It is made available under a CC-BY-NC-ND 4.0 International license .

Figure 1: Temporal relationship between community incidence of COVID-19 and outbreaks in Ontario’s 623 nursing homes (April 8-July 16, 2020)

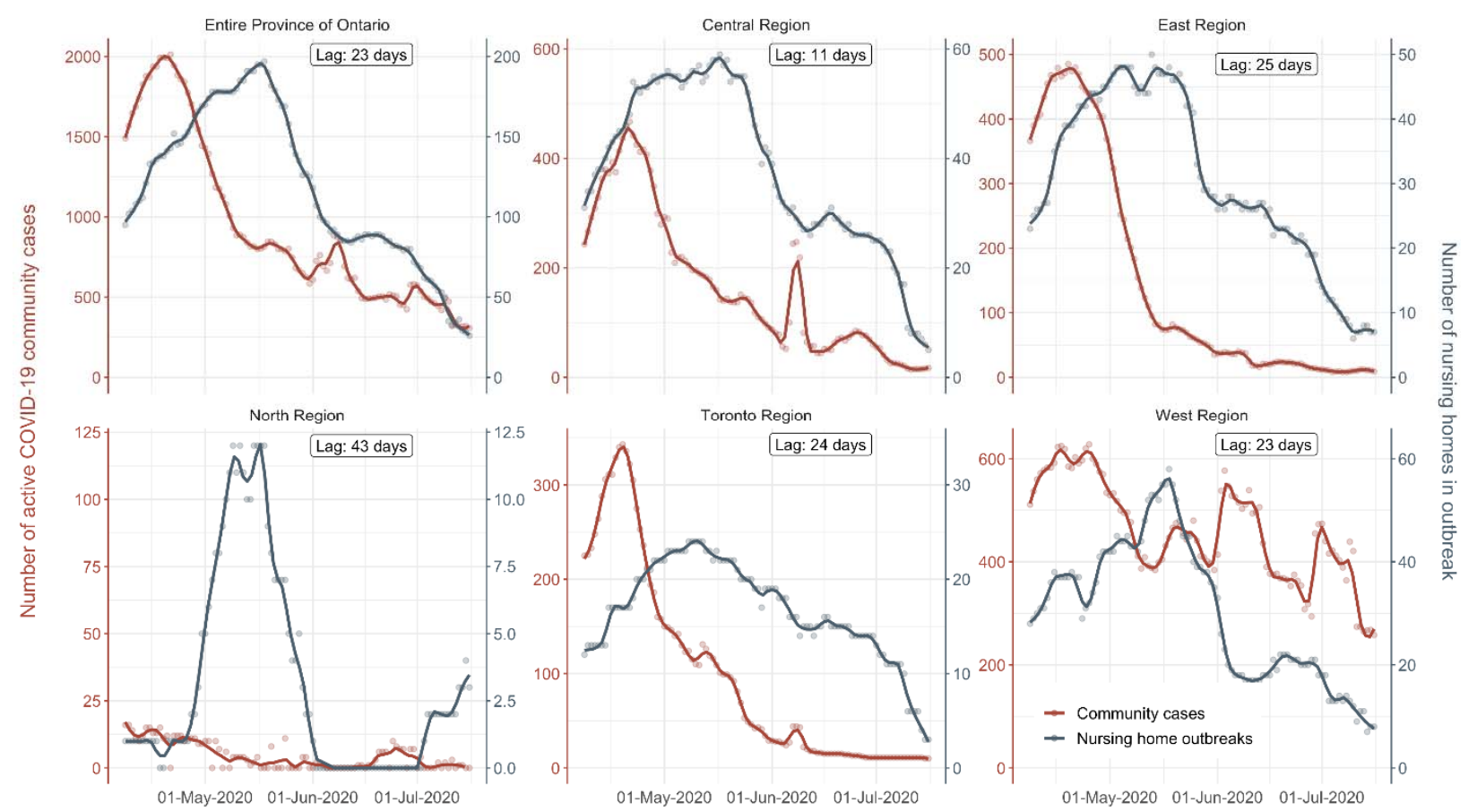

All active COVID-19 community cases (cumulative cases less resolved cases and deaths) and COVID-19 nursing home outbreaks in the Province of Ontario were calculated during the period from March 1 - April 8, 2020, after which we evaluated the temporal relationship between cases and outbreaks from April 8 - July 16, 2020. Results are displayed for the entire Province of Ontario and its 5 provincial health regions. The reported lag times indicate the number of days most correlated between active COVID-19 community cases and nursing home outbreaks. 
medRxiv preprint doi: https://doi.org/10.1101/2020.11.17.20233312; this version posted November 19, 2020. The copyright holder for this preprint (which was not certified by peer review) is the author/funder, who has granted medRxiv a license to display the preprint in perpetuity.

It is made available under a CC-BY-NC-ND 4.0 International license .

Table 1: Characteristics of Ontario's 623 nursing homes and lag times between community incidence of COVID-19 and nursing home outbreaks (March 1-July 16, 2020)

\begin{tabular}{|c|c|c|c|c|c|c|c|}
\hline \multirow[t]{2}{*}{$\begin{array}{l}\text { Geographic } \\
\text { region }\end{array}$} & \multirow[t]{2}{*}{$\begin{array}{l}\text { Population } \\
\text { density per } \\
\text { square } \\
\text { kilometre }^{\mathrm{a}}\end{array}$} & \multirow[t]{2}{*}{$\begin{array}{l}\text { Number of } \\
\text { nursing } \\
\text { homes }\end{array}$} & \multirow[t]{2}{*}{$\begin{array}{l}\text { Number of } \\
\text { nursing } \\
\text { home } \\
\text { residents }\end{array}$} & \multirow[t]{2}{*}{$\begin{array}{l}\text { Cumulative } \\
\text { COVID-19 } \\
\text { cases in } \\
\text { residents }\end{array}$} & \multicolumn{3}{|c|}{$\begin{array}{l}\text { Threshold of daily active } \\
\text { COVID-19 community cases } \\
\text { per } 100,000 \text { population } \\
\text { resulting in a } 75 \% \text { probability } \\
\text { of a future nursing home } \\
\text { outbreak }\end{array}$} \\
\hline & & & & & 5 days & 10 days & 15 days \\
\hline Central & 294.4 & 123 & 17,315 & 2,273 & 2.93 & 4.02 & 5.84 \\
\hline East & 64.7 & 165 & 20,327 & 1,936 & 1.88 & 5.53 & 6.38 \\
\hline North $^{\mathrm{c}}$ & 1.0 & 63 & 6,495 & 17 & - & - & - \\
\hline Toronto & $6,412.6$ & 36 & 5,695 & 739 & 3.52 & 9.63 & 13.58 \\
\hline West & 94.9 & 236 & 25,844 & 716 & 1.83 & 3.07 & 1.64 \\
\hline Ontario & 14.8 & 623 & 75,676 & 5,681 & 2.30 & 3.65 & 3.93 \\
\hline
\end{tabular}

${ }^{a}$ Source: Ontario Ministry of Finance, based on 2016 Canadian Census.

${ }^{\mathrm{b}}$ Daily active COVID-19 community cases per 100,000 population. All active COVID-19 community cases (cumulative cases less resolved cases and deaths) and COVID-19 nursing home outbreaks in the Province of Ontario were calculated during the period from March 1 - April 8, 2020, after which we conducted logistic regression on all active cases and nursing home outbreaks from April 8 - July 16, 2020.

${ }^{\mathrm{c}}$ Threshold calculations for the North Region were suppressed due to the small numbers of reported cases and small population size. 